\title{
Effect of Environmental Education Modul towards Pupils Knowledge and Behaviour Intention among Primary Pupils
}

Kartini Mohd Ismail, Ahmad Fauzi Mohd Ayub, Rosta Harun Tamil Selvam Subramanian

To Link this Article: http://dx.doi.org/10.6007/IJARBSS/v11-i7/9241

DOI:10.6007/IJARBSS/v11-i7/9241

Received: 18 May 2021, Revised: 22 June 2021, Accepted: 08 July 2021

Published Online: 26 July 2021

In-Text Citation: (Ismail et al., 2021)

To Cite this Article: Ismail, K. M., Ayub, A. F. M., \& Subramanian, R. H. T. S. (2021). Effect of Environmental Education Modul towards Pupils Knowledge and Behaviour Intention among Primary Pupils. International Journal of Academic Research in Business and Social Sciences, 11(7), 402-407.

Copyright: (c) 2021 The Author(s)

Published by Human Resource Management Academic Research Society (www.hrmars.com)

This article is published under the Creative Commons Attribution (CC BY 4.0) license. Anyone may reproduce, distribute, translate and create derivative works of this article (for both commercial and non-commercial purposes), subject to full attribution to the original publication and authors. The full terms of this license may be seen at: http://creativecommons.org/licences/by/4.0/legalcode

Vol. 11, No. 7, 2021, Pg. 402 - 407

Full Terms \& Conditions of access and use can be found at http://hrmars.com/index.php/pages/detail/publication-ethics 


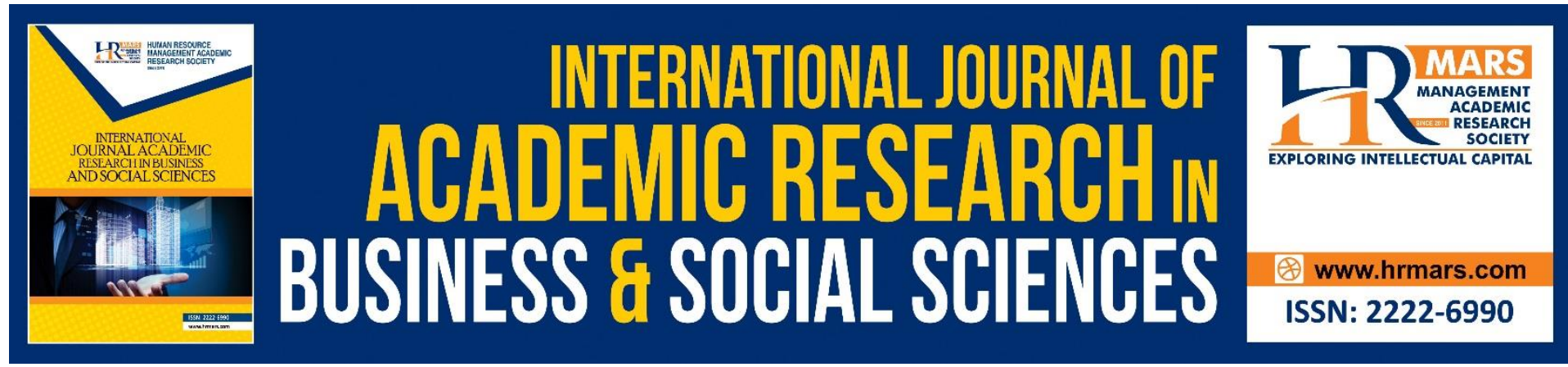

\title{
Effect of Environmental Education Modul towards Pupils Knowledge and Behaviour Intention among Primary Pupils
}

\author{
Kartini Mohd Ismail ${ }^{1}$, Ahmad Fauzi Mohd Ayub², Rosta Harun ${ }^{3}$ \\ Tamil Selvam Subramanian ${ }^{4}$ \\ ${ }^{1,3}$ Forestry and Environment, Serdang, Universiti Putra Malaysia, ${ }^{2}$ Faculty of Educational \\ Studies, Serdang, Universiti Putra Malaysia, ${ }^{4}$ Vocational Education, Universiti Tun Hussein \\ Onn, Malaysia
}

\begin{abstract}
This study was undertaken in response to evaluate an instructional method in Environmental Education which is the Environmental Education Module in enhancing pupils' knowledge and behavior intention. One group pre and the post-quasi-experimental study was conducted involves 32 primary five pupils from two identified schools via purposive sampling. Four series of test were conducted namely pre-test (to access initial level of knowledge and behavior intention before intervention), post-test (to access immediate effects of intervention), onemonth post-delayed test (to access continuous effects of intervention) and six months postdelayed test (to access continuous and long-term effects of intervention). Based on the analysis of Repeated Measure ANOVA it is found that there is a significant difference in knowledge Wilks' Lambda $=.409, F(3,29)=13.951, p=.00<0.005$, eta ${ }^{2}=.591$ and in behavior intention Wilks' Lambda $=.60, F(3,29)=1.193, p=0.002<0.005$, eta ${ }^{2}=.04$. Thus, hypothesis $\mathrm{H}_{\mathrm{o} 1}$ and $\mathrm{H}_{\mathrm{o} 2}$ were rejected. Further analysis by pairwise comparison, Post $\mathrm{Hoc}$ with Bonferroni adjustment found that there is a statistically difference found in knowledge in the pair of posttest $(M=15.53, S D=2.94)$ compare to the pre-test $(M=11.50, S D=3.50$, one month postdelayed test $(M=15.28, S D=2.79)$ compare to the pre-test $(M=11.50, S D=3.50)$ and six months post-delayed test $(M=14.75, S D=2.90)$ compare to the pre-test $(M=11.50, S D=$ 3.50). This indicates that the module able to give positive impacts to enhance pupils' knowledge towards the environment and persist it until six months upon completion of the intervention. On the other hand, a similar result was also found in behavior intention in the pair of post-tests $(M=4.12, S D=0.31)$ when compared pre-test $(M=3.88, S D=3.041)$. This indicates that the module able to trigger and enhance the behavior intention towards the environment for a very short time. This suggested that the usage of the module as the main teaching and learning tool is capable of enhancing knowledge and behavior intention.
\end{abstract}

Keywords: Environment Education, Modular Approach, Behavior Intention, Knowledge

\section{Introduction}

Nowadays, humankind faces numerous environmental issues, along with rapid development globally. These imbalances had occurred in the ecological system as natural 
disasters such as global warming, air pollution, water pollution, ozone depletion, dwindling of natural resources, and an increase in residual waste (Mahat et.al, 2019). Biologist sees that all of these disruptions and threats as a warning that the Earth is reaching its limits. Research by Firdaus (2016), also highlighted that the destruction of the environment is caused by attitude and insufficient knowledge about the cause and effects of their actions towards the environment and its impacts on humanity itself. Under all the circumstances stated above, education is one of the best methods to create a generation with knowledge, awareness, and strong implementation of the practice of sustainability (Mahat et.al, 2019). It is also the best approach to shaping the generation that is environmentally knowledgeable and equipped with an awareness of nature (Ahmad et al., 2011). Additionally, Kartini (2007) also found that environmental education is suitable to enhance knowledge, attitude, and awareness towards environmental issues and problems. In Malaysia, environmental education (EE) is conducted via formal and informal education. Informal education, environmental education was not taught as a single subject (Damanhuri et al., 2016). It was a cross-curricular element that been integrated through a few subjects since 1993. It was a cross-curricular element that been integrated through a few subjects since 1993. Research stated that the integration was not successfully executed and did not achieve its objectives (Gan, 1987; Mageswary et. al., 2006; Lim, 2014 \& Abdul Rahman, 2017) thus the role of in-formal education is essential to infuse the element in environmental education.

In in-formal education, efforts were put through by government and non-government organizations, NGOs. This in-formal education was conducted in various ways. For example, the Awareness Camp (initiated in 1994), Wira Alam Project (initiated in 1998), Green School Projects (initiated in 2003), Environment Scrap Book Competition, Talks on Environmental Awareness, 3R Programmed, Environmental Week and others (Abdul Rahman, 2017; Abdul Mutalib, 2007; Ahmad \& Abdul Razak, 2007).

One of the initial projects and most actively organized is the Awareness Camp (KEKaS). This camp was launched with the purpose generally to promote the knowledge, attitude, and awareness of students and teachers towards the environment through the camping activities. To ensure the camp achieved its objectives, the government also established modules that act as the main teaching and learning tools in the camps. A series of the module was published in 1996 to facilitate the teaching and learning process.

Although the camp was started 20 years ago the impacts or outcomes from the camps were not investigated. This was confirmed by the officer-in-charge via a verbal interview. The reports available in the annual reports were only on the frequencies of the camp organized, the numbers of participants involved, and the locations of the camps were conducted which does not reflect the outcomes of such interventions.

Besides, in 2003 Annual Reports published by the Department of Environment (DOE), the government had allocated RM 330,000 to sponsor the execution of the camps in Malaysia for that particular year. Logically, the government had spent millions of ringgits through these camps to educate the people about the environment, but the impacts were unknown. Thus, a study regarding the effectiveness or the impacts of the program needs to be established to see the impacts and the worthiness of the investment.

According to Sidek and Jamaluddin, (2005), one of the characteristics of a good module is that the module must have a pre and post-test components to access the existing students' level of knowledge before using the module in the pre-test (at the beginning) and post-test that contain the similar items to access the improvements of the instructional methods used. Furthermore, Russell (1974) in his Modular Approach Model state that a 
module is proven to be effective when it can improve the knowledge and attitude of students after using it. This indicates that an evaluation of the effectiveness of the module in the camp needs to be conducted. The evaluation of the effectiveness of the EE Module in enhancing student's knowledge and behavior intention is important to evaluate the changes. Based on the justification above, it is found that there is a need to establish a study to evaluate the effectiveness of the module.

\section{Objective of the Study}

The objective of this study is to determine

a. the effect of an environmental education module on pupils' knowledge between pretest, post-test, one-month post-delayed test, and six-month post-delayed test among primary pupils

b. pupils' behavior intention towards the environment between pre-test, post-test, onemonth post-delayed test, and six-month post-delayed test among primary pupils

\section{Research Hypothesis}

Based on the objective mentioned before, two research hypotheses were constructed:

1. $\mathrm{H}_{01}$ : There is no significant difference in the overall mean scores in knowledge between pre-test, post-test, one-month post-delayed test, and six-month post-delayed test among primary pupils.

$2 \quad \mathrm{H}_{\mathrm{o} 2}$ : There is no significant difference in the overall mean scores in behavior intention between pre-test, post-test, one-month post-delayed test, and six-month post-delayed test among primary pupils.

\section{Methodology}

The one group pre-and post-test quasi-experimental study with repeated measure design is adopted in this study to determine the effectiveness of the independent variable which is the EE module in enhancing pupils' knowledge and behavior intention towards the environment (dependent variables) (Darusalam \& Hussean, 2016). One group or without a controlled study had been adapted when randomization or a control group cannot be established due to the hardship to find a similar sample that matched the characteristics of the treatment group or few other limitations.

TABLE 1. Overview of The Research Design

\begin{tabular}{|c|c|c|c|c|c|}
\hline Group & $\begin{array}{l}\text { Pre- } \\
\text { Test }\end{array}$ & Treatment & $\begin{array}{l}\text { Post- } \\
\text { Test }\end{array}$ & $\begin{array}{l}\text { One Month } \\
\text { Post-Delayed } \\
\text { Test }\end{array}$ & $\begin{array}{l}\text { Six Months } \\
\text { Post-Delayed } \\
\text { Test }\end{array}$ \\
\hline Experimental & $\begin{array}{l}\mathrm{O}_{1 \mathrm{a}} \\
\mathrm{O}_{2 \mathrm{a}}\end{array}$ & $\mathrm{X}$ & $\mathrm{O}_{1 b}, \mathrm{O}_{2 b}$ & $\mathrm{O}_{1 c}, \mathrm{O}_{2 c}$ & $\mathrm{O}_{1 \mathrm{~d}}, \mathrm{O}_{2 \mathrm{~d}}$ \\
\hline \multicolumn{6}{|c|}{$\begin{array}{l}\mathrm{O}_{1 \mathrm{a}}, \mathrm{O}_{2 \mathrm{~b}} \text { : Pre-test knowledge test which was administrated before the usage of the } \mathrm{EE} \\
\text { module. }\end{array}$} \\
\hline $\begin{array}{l}\mathrm{O}_{1 b}, \mathrm{O}_{2 b} \\
\text { module }\end{array}$ & \multicolumn{5}{|c|}{ : First post-test which was administrated immediate after the usage of the $E E$} \\
\hline \multicolumn{6}{|c|}{$\begin{array}{l}\mathrm{O}_{1 c}, \mathrm{O}_{2 c}: \text { One-month post-delayed test which was administrated after one month the usage } \\
\text { of the EE module. }\end{array}$} \\
\hline
\end{tabular}


$\mathrm{O}_{1 \mathrm{~d}} \cdot \mathrm{O}_{2 \mathrm{~d}}$ : Six -months post-delayed test which was administrated after six months of the usage of the EE module.

\section{Sample}

This study involves 40 samples from two identified primary schools under the supervision of Petaling Jaya City Council (MBPJ). The method of sampling adopted in this study was purposive sampling. According to Fraenkel and Wallen (2008) this method of sampling is suitable for the specific purpose to evaluate the effectiveness of program or intervention. In purposive sampling, the researcher intentionally selects individuals and sites to learn or understand the central phenomenon (Creswell, 2012).

\section{Instrument}

The instruments used in this research were adapted mainly from two sources namely Kartini (2007) and Yaakub (2013). The questionnaire was modified and adapted so that the new instruments are relevant to the objective of the research and the respondents. There are four sets of instruments used in this research, namely the pre-test instrument, immediate post-test instrument, one-month post-delayed test instrument, and six-months post-delayed test instrument.

TABLE 2: Summary of Instrument

\begin{tabular}{lll}
\hline Component & Scale & Items \\
\hline $\begin{array}{l}\text { Demographic Profile } \\
\text { Knowledge towards the }\end{array}$ & - & - \\
$\begin{array}{l}\text { environment } \\
\text { Behavior Intention towards } \\
\text { the environment }\end{array}$ & 5-point Likert Scale & 25 \\
\end{tabular}

The preliminary data analysis was examined by Explanatory data Analysis (EDA) via statistical and visual inspections to ensure that the data meet the normality assumption. Statistical analysis that was employed in this research is the descriptive analysis to obtain the frequency, percentage, mean and standard deviation, and inferential analysis. Inferential analysis by using Repeated Measure ANOVA was chosen to test the difference of knowledge and behavior intention towards an environment in pre-tests, post-tests, one-month postdelayed tests, and six-months post- delayed test.

\section{Result and Discussion}

The result and discussion for the study is based on the objectives given.

\section{a. the effect of an environmental education module on pupils' knowledge}

The first analysis is to test whether there is a significant difference in the overall mean scores in knowledge between pre-test, post-test, one-month post-delayed test, and six-month postdelayed test among primary pupils. Table 3 indicated the mean and standard deviation for the three performance tests. The mean score for the post-test, one-month post-delayed test, and six-month post-delayed test are higher than the mean score pre-test. Meanwhile, the mean score for a one-month post-delayed test and six-month post-delayed are slightly lower compared to the post-test mean score. 
TABLE 3. Descriptive Statistics for Knowledge Towards Environment In With Statistics Test Score For Pre-Test, Post-Test One Month Post Delayed Test and Six Months Post-Delayed Test.

\begin{tabular}{llcl}
\hline Test & N & Mean & Std. Deviation \\
\hline Pre-Test & 32 & 11.50 & 3.50 \\
Post-Test & 32 & 15.53 & 2.94 \\
One Month Post-Delayed Test & 32 & 15.28 & 2.79 \\
Six Months Post-Delayed Test & 32 & 14.75 & 2.90 \\
\hline
\end{tabular}

From the result of repeated measure ANOVA (see Table 4). If a statistically significant difference $(p<0.05)$ at the alpha level= 0.05 , was found, the pairwise comparison/ Post Hoc test with the Bonferroni adjustments was executed to further analyses which pair of tests differed from another pair of the test. There was a significant effect for time, Wilks' Lambda= $0.409, F(3,29)=13.951, p=0.00<0.005$, eta ${ }^{2}=0.591$ (See Table 4). From the result from the Repeated Measure ANOVA, it is found that there is a significant difference in the mean score of knowledge towards the usage of EE module in the pre-test $(M=11.50, S D=3.50)$, post-test $(M=15.53, S D=2.94)$, one-month post-delayed test $(M=15.28, S D=2.79)$ and six months postdelayed test $(M=14.75, S D=2.90)$. This suggested that there is a significant difference in the knowledge of the pupils towards the environment in the pre-test (before the usage of $\mathrm{EE}$ module), post-test (immediately after the usage of EE module), one-month post-delayed test (after one-month usage of EE module) and delayed six months (six months after the usage of EE module).

Table 4. Multivariate Tests for Knowledge Towards Environment in Pre-Test, Post-Test One Month Post Delayed Test and Six Months Post-Delayed Test

\begin{tabular}{llllllll}
\hline Effect & Value & $\mathrm{F}$ & $\begin{array}{l}\text { Hypothesis } \\
\text { df }\end{array}$ & Error df & Sig. & $\begin{array}{l}\text { Partial Eta } \\
\text { Squared }\end{array}$ \\
\hline Wilks' Lambda & .409 & 13.951 & 3.00 & 29.00 & .000 & .591 \\
\hline
\end{tabular}

Hence, based on the results presented, hypothesis one, $\mathrm{H}_{01}$ which states that there is no significant difference in the overall mean scores in knowledge between pre-test, post-test, one-month post-delayed test, and six-month post-delayed test among primary pupils is rejected. Post Hoc test was performed with the Bonferroni adjustments to further analyses which pair of tests differed from another pair of tests. This pairwise comparison with the Holm's Sequential Bonferroni was conducted only if there is a significant difference $(p<0.05)$ in the previous test. By consulting the significance levels in the post-test $(M=15.53, S D=2.94)$, one month post-delayed test $(M=15.28, S D=2.79)$ and six months post-delayed test $(M=$ $14.75, S D=2.90)$ has statistically significantly different when compare to the pre-test $(M=$ $11.50, S D=3.50)$.

The result had shown that there is a significant difference in the mean score of knowledge towards the usage of the EE module in the post-test compared to pre-test, onemonth post-delayed test compared to pre-test and six months post-delayed test compared to the pre-test. This indicated that the usage of the EE module has positive effects in enhancing the knowledge compared to the pre-test. 
Based on the Russell Model formula, the EE module also effective in enhancing the pupils' knowledge towards the environment in the post-test, one-month post-delayed test, and six months post-delayed test. The effect size on the usage of the EE module is also significant (eta $\left.{ }^{2}=0.591\right)$ [23]

However, there were no statistically significant found when compared one-month postdelayed test $(M=15.28, S D=2.79)$ with post-test $(M=15.53, S D=2.94)$ and six month postdelayed test $(M=14.75, S D=2.90)$ with post-test $(M=15.28, S D=2.79)$. Comparison between six months post-delayed test $(M=14.75, S D=2.90)$ and one-month post-delayed test $(M=$ $15.28, S D=2.79$ ) had also shown the same result as mentioned above.

Statistically, there is no significant difference in the pupils' knowledge towards the environment after one month (one-month post-delayed test) of the usage of the EE module compared to the immediate post-test (post-test) and also after six months (six months postdelayed test) when compared to immediate post-test (post-test). Besides, there was no significant difference found between the pair of six months post-delayed test compared to a one-month post-delayed test. This finding has shown that the knowledge of the pupils towards the environment remains the same after one month and six months after the usage of the EE module. This suggested that the EE module able to ignite changes in pupils' knowledge towards the environment and retains until six months upon completion of the usage of the EE module.

\section{b. pupils' behavior intention towards the environment}

The next analysis is to test the significant difference in the overall mean scores in behavior intention between pre-test, post-test, one-month post-delayed test, and six-month postdelayed test among primary pupils. Table 5 showed that overall mean for behavior intention post-test, one-month post-delayed test, and the six-month post-delayed test is higher than the pre-test. 
TABLE 5. Descriptive Statistics for Behavior Intention Towards the Environment in With Statistics Test Score For Pre-Test, Post-Test, One Month Post Delayed Test And Six Months Post-Delayed Test

\begin{tabular}{llll}
\hline Test & N & Mean & Std. Deviation \\
\hline Pre-Test & 32 & 3.88 & 0.41 \\
Post-Test & 32 & 4.12 & 0.31 \\
One Month Post-Delayed Test & 32 & 4.05 & 0.53 \\
Six Months Post-Delayed Test & 32 & 4.00 & 0.60 \\
\hline
\end{tabular}

There was a significant effect for time, Wilks' Lambda $=0.60, F(3,29)=1.193, p=0.002<0.005$, multivariate partial eta squared $=.04$ (see Table 6 ). It is also found that there is a significance difference in the behavior intention towards the usage of EE module in the pre-test $(M=3.88$, $S D=3.0 .41)$, post-test $(M=4.12, S D=0.31)$, one month post-delayed test $(M=4.05, S D=0.52)$ and six months post-delayed test $(M=4.00, S D=0.60)$. The effect size is large [23]. This indicated that the hypothesis two, $\mathrm{H}_{02}$ which states that there is no significant difference in the overall mean scores in behaviour intention between pre-test, post-test, one-month postdelayed test and six-month post-delayed test among primary pupils is rejected.

TABLE 6. Multivariate Test for Behavior Intention Towards Environment in Pre-Test, Post-Test One Month Post Delayed Test and Six Months Post-Delayed Test

\begin{tabular}{|c|c|c|c|c|c|c|}
\hline Effect & Value & $\mathbf{F}$ & $\begin{array}{l}\text { Hypothesis } \\
\text { df }\end{array}$ & df & Sig. & $\begin{array}{l}\text { Partial } \\
\text { Eta } \\
\text { Squared }\end{array}$ \\
\hline Wilks'Lambda & .600 & 6.447 & 3.00 & 29.00 & .002 & .400 \\
\hline
\end{tabular}

Based on the result above, it is found that there is a significant difference in the behavior intention of the pupils towards the environment in the pre-test (before the usage of $E E$ module), post-test (immediately after the usage of EE module), one-month post-delayed test (after one-month usage of EE module) and delayed six months (six months after the usage of EE module). Bonferroni adjustments were employed to further analyzed which pair of tests differed from another pair of tests by using the Post-hoc test. This step is essential only if there is a significant difference $(p<0.05)$ in the previous test. By consulting the significance levels in the Table 4.28 there are statistically significant difference in the pair of post-tests $(M=4.12, S D=0.31)$ compared pre-test $(M=3.88, S D=3.0 .41)$. The result had shown that there is a significant difference in the behavior intention towards the usage of the EE module in the post-test compared to the pre-test. This suggested that the usage of the EE module has positive effects on the behavior intention of the pupils compared to the pre-test. The EE module is also able to enhance pupils' behavior intention after the usage of its immediate (short term). However, there were no statistically significance difference observed in the sixmonth post-delayed test post-test $(M=4.05, S D=0.52)$ compared to pre-test $(M=3.88, S D=$ $0.41)$, six months post-delayed test $(M=4.05, S D=0.52)$ compared to pre-test $(M=3.88, S D=$ 3.0.41). In addition, there were also no significance difference detected in one-month postdelayed test $(M=4.05, S D=0.52)$ compared to post-test $(M=4.12, S D=0.31)$, six months postdelayed test $(M=4.05, S D=0.52)$ compared to post-test $(M=4.12, S D=0.31)$, and six months 
post-delayed test $(M=4.05, S D=0.52)$ compared to one-month post-delayed test $(M=4.05$, $S D=0.52$ ).

Statistically, there is no significant difference in the pupils' behavior intention towards the environment after one month (one-month post-delayed test) of the usage of the EE module compared to the pre-test, after six months (six months delayed -post-test) compared to pre-test, after one month (one-month post-delayed test), after six months (six months delayed post-test) compared to immediate post-test (post-test) and after six months (six months delayed post-test) compared to after one month (one-month post-delayed test) of the usage of the EE module. This suggested that the EE module unable to enhance the pupils' behavior intention towards the environment in the long term as the retention of the behavior intention is not successfully retained.

\section{Discussion}

Inferential analysis by using the Repeated Measures ANOVA had shown that there are significant effects for a time in the knowledge towards the environment. (Wilks' Lambda= $0.409, F(3,29)=13.951, p=0.00<0.005$, eta $\left.{ }^{2}=0.591\right)$. The significant differences found in knowledge towards the environment between the series of tests namely pre-test $(M=11.50$, $S D=3.50)$, immediate post-test $(M=15.53, S D=2.94)$, delayed one-month post-test $(M=15.28$, $\mathrm{SD}=2.789)$ and six months post delayed test $(M=14.75, S D=2.90)$. This proves that there are differences found in the knowledge of the pupils after the usage of the Environmental Education Module. The usage of the module had an impact on the pupils' knowledge after the teaching and learning session by using it.

Pairwise comparison analysis had shown that there is the significant difference found between the pair of immediate post-tests $(M=15.53, S D=2.94)$ compared to pre-test $(M=$ $11.50, S D=3.50)$, the pair of one month post delayed test $(M=15.28, S D=2.79)$ compared to pre-test and the pair of six months delayed post-test $(M=14.75, S D=2.90)$ compared to the pre-test. By referring to the pairwise comparison result stated previously in Table 4.1.3, it is proved that the usage of the Environmental Education Module as the main teaching and learning materials in the Awareness Camp able to promote pupil's knowledge towards the environment immediately after the usage. The module was also capable of enhancing pupils' knowledge after one month and after six months of usage. The result of effect size also indicated that the effects of the module towards the pupils' knowledge are very large ( $\mathrm{eta}^{2}=$ 0.591).

This indicates that the usage of Environmental Education module is effective to enhance the pupils' knowledge and the content of the module capable of retaining the enhancement of knowledge for six months after the usage of it. This finding is in agreement with the research conducted by Ismail (2013); Abdul Mutalib (2007); Covitt et.al (2005), where the usage of modules able to enhance knowledge of the respondents. The content of the module is still valid and capable to promote knowledge about the environment, although it's been 20 years since it was established.

No significant differences found in between the pair of immediate post-tests $(M=15.53$, $S D=2.94)$ compared to one month post delayed test $(M=15.28, S D=2.79)$, the pair of immediate post-test $(M=15.53, S D=2.94)$ compared to delayed six month post-test $(M=$ $14.75, S D=2.90)$ and the pair of delayed six month post-test $(M=14.75, S D=2.90)$ compared to one month post delayed test $(M=15.28, S D=2.79)$. This indicates that statistically, the knowledge of pupils remains the same until six months after the usage of the module. The module is unable to shift the knowledge to a higher level by a single user. Repetition or 
continuous usage of the module might help in enhancing the knowledge to a higher level and prevent reduction. As mentioned by Ausubel (2000), 'overlearned by repetition' can help in strengthening the newly learned meanings. The idea of repetition was also suggested by Slavin (2006) to avoid data loss.

According to the Russell Module Framework, a module is proven to be effective when it is capable to enhance 'entry behaviour' after the usage of the module. From all findings discussed above, the Environmental Education Module as the main teaching and learning material in the Awareness Camp is found to be effective to enhance the pupil's knowledge towards the environment as the knowledge towards environment increased in all the posttest compared to pre-test or the initial level of knowledge before undergoes the teaching and learning by using the module. The module also capable of retains the enhancement of pupils' knowledge for almost six months after the usage of it.

Result of Repeated Measure ANOVA indicated that there are significant effects for time in the behaviour intention towards environment (Wilks' Lambda $=0.60, F(3,29)=1.193$, $p=0.002<0.005$, eta $\left.{ }^{2}=.04\right)$. The significance difference found in behaviour intention were found among pre-test $(M=3.88 S D=0.41)$, immediate post-test $(M=4.12 S D=0.31)$, onemonth post-delayed test $(M=4.05 S D=0.53)$ and six months post delayed test $(M=4.0 S D=$ 0.60). This indicates that there are differences in the behavior intention after the usage of the Environmental Education Module as the main teaching and learning material in the Awareness Camp. This result showed that the Environmental Education Module able to enhance the pupils' behavior intention towards the environment after the usage of it as there was a positive difference among the mean scores. By referring to the Russell Module Framework, the Environmental Education Module is proven to be effective to enhance the behavior intention of the pupils towards the environment as it was able to enhance the behavior intention after the usage of it.

The similar findings in intervention by using module by Lim (2014) where the module of the interpretive program had successfully influenced the pupils' intention to involved as an organizer of an education program in school. Research by Covitt et al., (2005) also found that the module intervention used able to enhance the intention to apply the risk knowledge. Besides that, Masoumeh (2014), had also found that the Go Green intervention had proven to be successful in increasing the intention of the respondents to change the behavior towards protecting the environment.

Pairwise comparison analysis by using Bonferroni adjustment had shown that there are significant differences found between the pair of immediate post-tests $(M=4.12, S D=0.31)$ compare to the pre-test $(M=3.88, S D=3.0 .41)$. This indicates that the Environmental Education Module able to enhance the pupils' behaviour intention towards the environment after undergoes the teaching and learning process by using it. Although the changes are small but still the Environmental Education Module able to trigger the positive effects in the pupils' behaviour intention towards the environment.

There were no significance difference found between the pairs of one month post delayed test $(M=4.05, S D=0.52)$ compared to pre-test $(M=3.88, S D=0.41)$, six months post delayed test $(M=4.05, S D=0.52)$ compared to pre-test $(M=3.88, S D=0.41)$, immediate posttest compared $(M=4.12, S D=0.31)$, to one month post delayed test $((M=4.05, S D=0.52)$, immediate post-test compared $(M=4.12, S D=0.31)$, to six months post delayed test $(M=4.05$, $S D=0.52)$ and one month post delayed test $(M=4.05, S D=0.52)$ compared to six months post delayed test $(M=4.05, S D=0.52)$. This signifies that the Environmental Education Module only able to enhance the pupils' behaviour intention for a very short term. 
The content in the Environmental Education Module only able to ignite the intention behaviour towards the environment but unable to retain the behaviour intention for a longer period. This proves that there is a need to revise, update, and upgrade the content so that the initiated behaviour intention can last longer. Repetition or continuous effort might be one of the keys to ensuring the retention of these components. Slavin (2006) also stated that reinforcement, repetition, or continuous activities should be carried out to minimize the effects of data loss. Monroe, (2003) also advocated that the cultivation of elements in environmental education may be more efficient if the initiatives involved a long terms strategy and many instances and Ausubel (2000) had also stated that 'overlearned by repetition or rehearsal' should be implemented to avoid the newly learned meanings to dissociated with time.

\section{Conclusion}

As for the summary, the usage of the environmental education module as the main teaching and learning tool in the Awareness camp conducted by MBPJ is effective and can enhance the knowledge and behaviour intention after the exposure to the module. Further improvements and revision of the module are needed to ensure the module is functioning well to achieve the objectives of environmental education. The usage of the Environmental Education module able to give positive impacts on the knowledge and behaviour intention of the pupils. This indicates that the usage of the module is effective in providing knowledge but not in other domains. The agency in-charge should seek other alternatives to replace the module or to upgrade the module itself as the main teaching and learning tool in the awareness camp. The module needs to upgrade and revised to ensure the effectiveness to trigger other domains like attitude, awareness, behaviour, and many more. Elements of the $21^{\text {st }}$ learning century might be incorporated in the module so that it suits the learning style of the current generation, especially primary pupils. Elements of collaboration, critical and creative thinking, and graphic organizer might be added to attract the pupils.

According to Noah and Ahmad (2006), one of the characteristics of a good module is that the module must have the pre and post-test components to access the existing level of knowledge of the pupils before using the module (at the beginning) and post-test that contain the similar items as in the pre-test to access the improvements of the instructional method used. The module needs to have a pre and post-test to access the effectiveness and evaluate the impacts of the teaching and learning process conducted. This study might provide a preliminary idea on the establish of the pre and post-test in the efforts of completing the missing elements in the module.

Monroe (2003) advocated that the cultivation of elements in environmental education may be more efficient if the initiatives involved a long terms strategy and many instances and Ausubel (2000) had also stated that 'overlearned by repetition or rehearsal' should be implemented to avoid the newly learned meanings to dissociated with time. Repetition and continuous efforts are elements that need to be given a focus so that the domains can be retained and persist in the pupils. The findings in this research might help the agency in charge or non-governmental organization to give ideas and contributions in planning, designing, and developing the new material for formal and informal education to achieve the ultimate goal of environmental education.

From all the findings and recommendations stated above, it is recommended that the agency in charge upgrade the present module or develop a new set of modules to trigger other domains rather than focusing on providing the knowledge. A new set of modules of 
continuous modules might also be considered as it is the key to ensure the retention of the domains triggered. A module which consists of elements related to the Sustainable Goal Development (SGD) might also be considered and taking into consideration to achieve sustainable development.

\section{References}

Abdul Rahman, H. (2017). Usaha dalam mengaplikasikan pendidikan alam sekitar dalam persekolahan di Malaysia. Asian Journal of Environment, History and Heritage, 1(2), 6170.

Abdul Mutalib, K. (2007). Penilaian keberkesanan modul pengajaran ekosistem hutan dalam meningkatkan pengetahuan dan sikap pelajar terhadap ekosistem hutan tropika. [Unpublished doctoral dissertation], Universiti Putra Malaysia.

Ahmad, J., Mustafa, H., Abd. Hamid, H., \& Abdul Wahab, J. (2011). Pengetahuan, sikap dan amalan masyarakat malaysia terhadap isu alam sekitar. Akademika, 81(3), 103-115.

Ahmad, M. Z., \& Abd Razak, N. (2007). Pendidikan alam sekitar di sekolah: Komitmen guru. Pendidikan Lestari. 7(2), 74-81.

Ausubel, D. P. (2000). The acquisition and retention of knowledge: A Cognitive view, Kluwer Academic Publisher.

Cohen, J. (1988). Statistical power analysis for the behavioral sciences ( $\left.{ }^{\text {nd }} . e d.\right)$ Lawrence Erlbaum Associates.

Covitt, B. A., Gomez-Schmidt, C., \& Zint, M. T. (2005). An evaluation of the risk education module. Journal of Environmental Education, 36(2), 3-13.

Creswell, J. W. (2012). Educational research: Planning, conducting, evaluating, quantitative and qualitative research ( $4^{\text {th }}$. ed.). Pearson.

Darusalam, G., \& Hussean, S. (2016). Metodologi penyelidikan dalam pendidikan. University of Malaya Press.

Fraenkel, J. R., \& Wallen, N. E. (2008). How to design and evaluate research in education. McGraw Hill.

Gan, S. L. (1987). Environmental education in Malaysia: Curriculum guideline for pre-service science teacher education programmed. [Unpublished master's thesis], University of Hawaii.

Hassan, F., Samin, N., \& Sulaiman, S. (2012). Penjanaan pendapatan dan inovasi pelajar melalui pendidikan alam sekitar. pendidikan alam sekitar. In Azizi M, Mohmadisa $\mathrm{H}$, Mohamed Yusri, S. C. G., \& Nasir, N. (Ed), Melestarikan kesedaran masyarakat di Malaysia, (pp. 71-92). Jabatan Geografi dan Alam Sekitar

Lim, E. A. L. (2014). Effectiveness of Interpretive Education Program in Influencing Rural Secondary School Students' Conservation Behaviour. [Unpublished doctoral dissertation], Universiti Putra Malaysia.

Mahat, H., Hashim, M., Saleh, Y., Nayan, N., \& Norkhaidi, S. B. (2019). Environmental Sustainability Knowledge, Attitude, and Practices among Pre-school Students (paper presentation). IOP Conference Series, 286(1029), 1-10. doi:10.1088/1755$1315 / 286 / 1 / 012003$

Masoumeh, H. (2014). Impacts of go green campaign on green behavior intention among consumers in Klang Valley, Malaysia. [Unpublished doctoral dissertation], Universiti Putra Malaysia.

Mageswary, K., Zurida, I., \& Norita, M. (2006). Knowledge, beliefs, desires, and behavior of chemistry pre-service teachers towards the environment. In Suan, Y., Ismail, M., 
Nurulazam, Fong, S. F., and Lim, C. S. (Eds), Proceedings for International Organization of Science and Technology Education Symposium 2006-Science and Technology Education in the Service of Humankind. Penang, Malaysia. (pp. 487-494)

Firdaus, M. O. S. (2016). Kesan program perkhemahan pendidikan luar terhadap sikap alam sekitar dalam kalangan pelajar sekolah menengah daerah Sabak Bernam. [Unpublished Master Thesis], Universiti Pendidikan Sultan Idris.

Noah, M. S., \& Ahmad, J. J. (2005). Pembinaan modul: Bagaimana membina modul latihan dan modul akademik. Universiti Putra Malaysia.

Monroe, M. C. (2003). Two avenues for encouraging conservation behaviors. Human Ecology Review, 10(2), 113-125.

Damanhuri, M. I., Ehambron, D., \& Yusuf, M. (2016). Tahap kesedaran dan amalan pendidikan alam sekitar dalam kalangan pelajar tingkatan 4 aliran sains di daerah Hulu Selangor. Geografi, 4(2), 28-35.

Russell, J. D. (1974). Modular instruction: A guide to the design, selection, utilization, and evaluation of modular materials. Burgess Publishing.

Ismail, S. N. (2013). Effects of project-based learning on environmental literacy of pre-service teachers at an institute of teacher education in Malaysia. [Unpublished PhD], Universiti Putra Malaysia.

Slavin, R. (2006). Educational psychology: Theory and practice. Allyn and Bacon.

Yaakub, S. (2013). Pembinaan dan pengesahan instrument literasi alam sekitar sekolah menengah. [Unpublished PhD], Universiti Sains Malaysia. 